\section{Yields of Organically Grown Sweet Pepper Cultivars and Lines during the Hot-wet and Cool-dry Season in the Tropics}

\author{
Peter Juroszek ${ }^{1}$ and Hsing-Hua Tsai
}

AdDITIONAL INDEX wORDs. Capsicum annumm, varieties, temperature, tolerant

SuMMARY. Organic production is considered by many researchers to be a viable alternative to conventional farming systems. Equivalent yields already have been demonstrated in several studies. The major objective of our study was to collect data on total and marketable fruit yields of sweet pepper (Capsicum annuиm) under organic farming conditions in the tropics. Experiments were conducted during the hot-wet season from 7 Mar. 2007 to 30 July 2007 and during the cool-dry season from 27 Nov. 2007 to 7 Apr. 2008. The six experimental entries included four commercial $\mathrm{F}_{1}$ hybrids and two genotypes bred at AVRDC-The World Vegetable Center (Shanhua, Taiwan). During the hot-wet season, high total (44.6-55.7 $\left.\mathrm{t} \cdot \mathrm{ha}^{-1}\right)$ and marketable yields $\left(36.9-45.6 \mathrm{t} \cdot \mathrm{ha}^{-1}\right)$ were achieved under organic farming conditions in the open field similar to yields of conventionally produced sweet pepper in previous field experiments at AVRDC. The total yield of the commercial cultivars Queen Star and Hercules exceeded $50 \mathrm{t} \cdot \mathrm{ha}^{-1}$; however, this was not significantly different compared with the other trial entries. During the cool-dry season, the total (25.4-45.7 $\left.\mathrm{t} \cdot \mathrm{ha}^{-1}\right)$ and marketable yields $\left(21.1-37.8 \mathrm{t} \cdot \mathrm{ha}^{-1}\right)$ of all trial entries were reduced, probably because the relatively late planting date in November and relatively low air temperature resulted in reduced fruit set. The commercial cultivars Andalus and Green Bell Improved realized in both seasons a total fruit yield of more than $40.0 \mathrm{t} \cdot \mathrm{ha}^{-1}$, suggesting that these can be grown successfully in hot-wet and cool-dry seasons. The relatively high yields of sweet pepper achieved on-station under tropical climatic conditions may encourage farmers and agricultural stakeholders to consider organic farming approaches as a viable alternative to conventional farming systems.

S weet pepper is an economically important crop for organic and conventional farmers. It is grown in most countries of the world (Bosland and Votava, 2000). Sweet pepper fruit are good sources of many essential nutrients, including vitamins $\mathrm{A}, \mathrm{C}$, and $\mathrm{E}$, carotenoids, minerals (e.g., calcium and iron), and other secondary plant compounds (Marin et al., 2004). Pesticide residues in fruit and vegetables are of concern to consumers; consequently, interest in organically grown organic fruit and vegetables has increased (United Nations, 2003).

AVRDC-The World Vegetable Center, Crop and Ecosystem Management Unit, Organic Vegetable Program, Yi-Min Liao 60, Shanhua, Taiwan 741.

Many thanks to the donors who supported AVRDC's Organic Vegetable Program, including BMZ/GTZ (Germany), The Organic Center for Education \& Promotion (U.S.), and the Council of Agriculture (Taiwan). We are particularly grateful to Field Assistant Ming-Jen Yang and his field team members for establishing and maintaining the field experiments. Special thanks to our colleagues Sheue-Chien Shieh (Pepper Unit), Dr. Chin-Hua Ma (Soil Science Group), Chien-Hua Chen (Mycology Unit), and Fu-Cheng Su (Entomology Unit). We are grateful to Dr. Paul Gniffke (Pepper Unit) for his valuable comments to improve this manuscript.

${ }^{1}$ Corresponding author. E-mail: peter.juroszek@worldveg. org. conducted in the United States, and by Cesar et al. (2007) undertaken in
Brazil, concluded that the yields of sweet pepper were similar in organic and conventional production systems. Chellemi and Rosskopf (2004) realized up to $30 \mathrm{t} \cdot \mathrm{ha}^{-1}$ of marketable sweet pepper fruit yield in humid subtropical Florida, and concluded that organic production systems for fresh market sweet pepper can produce yields similar to those obtained in conventional farming systems. In a recent greenhouse study, Del Amor (2007) has found that marketable yield of sweet pepper $\left(7.3 \mathrm{~kg} \cdot \mathrm{m}^{-2}\right)$ fertilized with organic fertilizer equaled yields of sweet peppers that received organic and mineral fertilizer. The author concluded that with a proper manure dosage, chemical fertilizer input could be reduced in sweet pepper cultivation, reducing production costs and groundwater pollution, without decreasing fruit yield.

It is beyond the scope of this study to discuss topics such as availability of high-quality seed, seed cost, and marketing opportunities of organically grown vegetables in the tropics, including sweet pepper. Interested readers are referred to publications cited in this article, such as Juroszek et al. (2008) and United Nations (2003). In contrast, this study sought to document the yields of organically grown sweet pepper under a tropical environment. Information on potential yields of organically grown sweet pepper under tropical climatic conditions can assist researchers in evaluating the yield performance of organically cultivated sweet pepper under tropical climatic conditions elsewhere. Decision makers in agriculture also benefit from knowing about the conditions under which organic production can be a viable alternative to conventional production systems.

\section{Materials and methods}

EXPERIMENTAL AREA AND CLIMATIC CONDITIONS. Research experiments of the Organic Vegetable

\begin{tabular}{llll}
\hline $\begin{array}{l}\text { Units } \\
\text { To convert U.S. to SI, } \\
\text { multiply by }\end{array}$ & U.S. unit & SI unit & $\begin{array}{l}\text { To convert SI to U.S., } \\
\text { multiply by }\end{array}$ \\
\hline 0.3048 & $\mathrm{ft}$ & $\mathrm{m}$ & 3.2808 \\
2.54 & inch(es) & $\mathrm{cm}$ & 0.3937 \\
25.4 & inch(es) & $\mathrm{mm}$ & 0.0394 \\
1.1209 & $\mathrm{lb} / \mathrm{acre}$ & $\mathrm{kg} \cdot \mathrm{ha}^{-1}$ & 0.8922 \\
4.8824 & $\mathrm{lb} / \mathrm{ft}^{2}$ & $\mathrm{~kg} \cdot \mathrm{m}^{-2}$ & 0.2048 \\
28.3495 & $\mathrm{OZ}$ & $\mathrm{g}$ & 0.0353 \\
2.2417 & ton/acre & $\mathrm{t} \cdot \mathrm{ha}^{-1}$ & 0.4461 \\
$\left({ }^{\circ} \mathrm{F}-32\right) \div 1.8$ & ${ }^{\circ} \mathrm{F}$ & ${ }^{\circ} \mathrm{C}$ & $\left(1.8 \times{ }^{\circ} \mathrm{C}\right)+32$ \\
& & &
\end{tabular}


Program of AVRDC were performed at the Center's headquarters in the tropical southwest of Taiwan, about $50 \mathrm{~km}$ south of the Tropic of Cancer and at about $40 \mathrm{~m}$ above sea level. The experimental site has been in organic production for about 3 years, adhering to the Production Standards for Organic Agricultural Products: Crops of Taiwan (Council of Agriculture, Taiwan, 2005). Monthly mean temperature during the hot-wet season from May to September ranges from 27.0 to $29.0^{\circ} \mathrm{C}$; during the cool-dry season from October to April the temperature ranges from 17.4 to $25.9^{\circ} \mathrm{C}$. Mean annual precipitation is about $1670 \mathrm{~mm}$, distributed bimodally. The mean precipitation during the hot-wet season from May to September is about $1450 \mathrm{~mm}$; during the cool-dry season from October to April, it is about $220 \mathrm{~mm}$ (Central Weather Bureau, Taiwan, 2008). The soil type is Sandstone-Shale Alluvium with lime concretions. The soil $\mathrm{pH}$ is about 7.5. The surface soil texture is silty loam. The experimental site was, in general, suitable for vegetable production, including sweet pepper.

WEATHER CONDITIONS DURING THE EXPERIMENTS. The on-farm field study was conducted during the hotwet season from 7 Mar. 2007 to 30 July 2007 [143 d after transplanting (DAT) ] and during the cool-dry season from 27 Nov. 2007 to 7 Apr. 2008 (132 DAT). Table 1 shows information on the prevailing air temperature, precipitation, and evaporation. In the first week of Oct. 2007, a typhoon contributed to the unusually high precipitation of $237 \mathrm{~mm}$; October is usually the beginning of the dry season with a monthly mean precipitation of about $30 \mathrm{~mm}$ (Central Weather Bureau, Taiwan, 2008). In Feb. 2008, the mean monthly minimum temperature was relatively low, at $\mathbf{1 2 . 9}$ ${ }^{\circ} \mathrm{C}$ compared with the long-term monthly mean of $14.5^{\circ} \mathrm{C}$ (Central Weather Bureau, Taiwan, 2008).

Cultivar selection. Cultivar choice did not specifically consider traits that may be desired particularly in organic farming (De Melo, 2003; Lammerts van Bueren, 2002). In general, the commercial cultivars selected were known to be high yielding under conventional farming conditions in Taiwan. In addition, one test hybrid and one advanced line bred at AVRDC were evaluated. Cultivars tested included Green Bell Improved (Evergrow Seed Co., Tainan City, Taiwan), Queen Star (KnownYou Seed Co., Kaohsiung, Taiwan), Hercules (Known-You Seed Co.) Andalus (Syngenta Seeds, Enkhuizen, The Netherlands), COA677 (AVRDC test $F_{1}$ hybrid), and PP9852-131 (AVRDC breeding line). All trial entries were $F_{1}$ hybrids except PP9852-131, which is open-pollinated (OP). The cultivars differed in maturity, fruit characteristics, growth habit, virus disease resistance, and tolerance to extreme temperatures (Table 2). During the cool-dry season, COA672 was used instead of COA677 because COA677 seed were not available. However, both are hybrids and their genetic background is very similar (Table 2).
Experimental Design. Sweet pepper seed were sown on 1 Feb. and were transplanted on 7 Mar. 2007 for the hot-wet season trial, and were sown on 22 Oct. and transplanted on 27 Nov. 2007 for the cool-dry season trial, respectively. The previous crop in both seasons was fallow. The trials were arranged as randomized complete-block designs with four replications. Plots were established as raised beds, covered with plastic film mulch. The plot size was $1.0 \mathrm{~m}$ wide $\times 4.5 \mathrm{~m}$ long. Furrow space between raised beds was $0.5 \mathrm{~m}$. Twenty plants were grown in double rows per plot. Spacing was $50 \mathrm{~cm}$ between rows and $45 \mathrm{~cm}$ between plants. The plants were staked.

Nitrogen fertilizer APPLICATION. In both seasons, according to the expected total yield of about $50 \mathrm{t} \cdot \mathrm{ha}^{-1}$, we applied about 300 $\mathrm{kg} \cdot \mathrm{ha}^{-1}$ nitrogen $(\mathrm{N})$ in sweet pepper at a rate and application method similar to those recommended for conventional sweet pepper production in the open field in Taiwan (AVRDC-The World Vegetable Center, 2004; C.H. $\mathrm{Ma}$, personal communication). According to this recommendation, commercial organic fertilizers were applied, including locally produced compost basal [about $1.8 \mathrm{~N}-4.5 \mathrm{P}-2.1 \mathrm{~K}$ (TenLo \#1; Ten-Lo Co., Tian-Chong, Taiwan)] at about $200 \mathrm{~kg} \cdot \mathrm{ha}^{-1} \mathrm{~N}$, soybean meal [about $7.5 \mathrm{~N}-1.6 \mathrm{P}-2.7 \mathrm{~K}$ (FwuSow Industrial Co., Lu-gang, Taiwan)] enriched with grass ash [about $0.1 \mathrm{~N}-$ 2.9P-33.8K (Fwu-Sow Industrial Co.)] in total four sidedressings each of about $25 \mathrm{~kg} \cdot \mathrm{ha}^{-1} \mathrm{~N}$, and a one-time

Table 1. Monthly weather records from Mar. 2007 to Mar. 2008 at AVRDC-The World Vegetable Center weather station, Shanhua, Taiwan.

\begin{tabular}{|c|c|c|c|c|c|}
\hline Month & $\begin{array}{c}\text { Mean monthly } \\
\text { minimum } / \text { mean } / \text { maximum air } \\
\operatorname{temp}\left({ }^{\circ} \mathrm{C}\right)^{\mathrm{z}}\end{array}$ & $\begin{array}{l}\text { Minimum daily } \\
\text { air temp }\left({ }^{\circ} \mathrm{C}\right)\end{array}$ & $\begin{array}{l}\text { Maximum daily } \\
\text { air temp }\left({ }^{\circ} \mathbf{C}\right)\end{array}$ & $\begin{array}{c}\text { Precipitation } \\
(\mathrm{mm})^{\mathrm{z}}\end{array}$ & $\begin{array}{c}\text { Evaporation } \\
(\mathrm{mm})\end{array}$ \\
\hline March 2007 & $18.3 / 22.6 / 26.9$ & 13.1 & 32.1 & 23 & 114 \\
\hline April 2007 & $19.6 / 23.9 / 28.2$ & 12.8 & 33.0 & 48 & 133 \\
\hline May 2007 & $23.5 / 27.4 / 31.3$ & 20.3 & 34.6 & 268 & 154 \\
\hline June 2007 & $25.5 / 29.2 / 32.9$ & 23.1 & 36.9 & 416 & 145 \\
\hline September 2007 & $25.4 / 29.1 / 32.9$ & 24.0 & 35.6 & 205 & 96 \\
\hline October 2007 & $22.9 / 26.6 / 30.4$ & 19.3 & 33.3 & 237 & 106 \\
\hline November 2007 & $19.0 / 23.1 / 27.2$ & 14.0 & 30.1 & 19 & 109 \\
\hline December 2007 & $16.7 / 21.3 / 26.1$ & 11.9 & 30.4 & 0 & 90 \\
\hline January 2008 & $15.2 / 19.6 / 24.0$ & 9.5 & 31.0 & 40 & 89 \\
\hline February 2008 & $12.9 / 16.6 / 20.3$ & 9.4 & 26.6 & 13 & 78 \\
\hline
\end{tabular}

${ }^{2}\left(1.8 \times{ }^{\circ} \mathrm{C}\right)+32={ }^{\circ} \mathrm{F}, \mathrm{l} \mathrm{mm}=0.0394$ inch. 
Table 2. Characteristics of sweet pepper cultivars and lines according to the product label of commercial hybrids or expert knowledge.

\begin{tabular}{|c|c|c|c|c|c|}
\hline Cultivar/line & Harvest $^{\mathrm{z}}$ & $\begin{array}{l}\text { Fruit color } \\
\text { and shape }\end{array}$ & $\begin{array}{l}\text { Fruit size }{ }^{\mathrm{z}} \\
\mathrm{L} \times \mathrm{W}(\mathrm{cm})^{\mathrm{x}}\end{array}$ & Fruit $w^{\mathrm{z}}(\mathrm{g})^{\mathrm{w}}$ & Traits $^{\mathrm{v}}$ \\
\hline $\begin{array}{l}\text { 'Green Bell } \\
\text { Improved' }\end{array}$ & Early to medium & $\begin{array}{l}\text { Dark green, } \\
\text { upright bell }\end{array}$ & $17 \times 8$ & 300 & $\begin{array}{l}\text { Strong flower set, heat } \\
\text { tolerant, TMV resistant }\end{array}$ \\
\hline 'Queen Star' & Early $(45 \text { DAT })^{\mathrm{u}}$ & $\begin{array}{l}\text { Bluish green, upright } \\
\text { conical bell }\end{array}$ & $14 \times 7$ & 220 & $\begin{array}{l}\text { Vigorous, early, uniform size and } \\
\text { high yielding, TMV tolerant }\end{array}$ \\
\hline 'Hercules' & Late (83 DAT) & Red, bell & $9 \times 7.5$ & $150-180$ & $\begin{array}{l}\text { Vigorous, thick crispy flesh, } \\
\text { PVY tolerant }\end{array}$ \\
\hline COA677 & Early $(<60$ DAT $)$ & $\begin{array}{l}\text { Yellowish green, } \\
\text { short bell }\end{array}$ & $6.2 \times 8.8$ & 190 & $\mathrm{~PB}$ (racel) and BS (racel) resistant \\
\hline COA672 & Early (<60 DAT) & $\begin{array}{l}\text { Yellowish green, } \\
\text { short bell }\end{array}$ & $9 \times 9$ & 210 & $\mathrm{~PB}$ (racel) and BS (racel) resistant \\
\hline PP9852-131 & Early $(<60$ DAT $)$ & $\begin{array}{l}\text { Yellowish green, } \\
\text { conical bell }\end{array}$ & $9.1 \times 3.6$ & 36 & CMV and PVY resistant \\
\hline
\end{tabular}

${ }^{2}$ Fruit harvest date, fruit size, and fruit weight can be different depending on cultivation methods used and growing conditions in different years and seasons.

${ }^{y}$ Fruit color of the immature fruit (color of mature fruit is red for each cultivar/line).

'Length of the fruit $\times$ width of the fruit, $\mathrm{l} \mathrm{cm}=0.3937$ inch.

${ }^{\mathrm{w}} \mathrm{l} \mathrm{g}=0.0353 \mathrm{oz}$.

${ }^{v} \mathrm{TMV}=$ tobacco mosaic virus, $\mathrm{PVY}=$ potato virus $\mathrm{Y}, \mathrm{PB}=$ phytophthora blight $($ Phytophthora capsici $), \mathrm{BS}=$ bacterial spot $($ Xanthomonas campestris $\mathrm{pv}$. vesicatoria $)$, CMV = cucumber mosaic virus.

"DAT $=$ days after transplanting.

homemade organic starter solution technology (OSST). The principle of OSST is to raise the $\mathrm{N}$ concentration in the soil by applying a concentrated $\mathrm{N}$ solution (derived through fermentation of sugar cane molasses and fish residues) immediately after transplanting to enhance early growth and overall yields of vegetable crops (AVRDC-The World Vegetable Center, 2008). When necessary, the crops were furrow-irrigated about every 2 to 3 weeks, usually immediately after applying fertilizer sidedressings to promote plant nutrient availability and uptake.

Pest incidence and plant PROTECTION. Few problems were encountered with plant diseases and pests during the hot-wet season in 2007, but during the cool-dry season, sweet pepper plants were challenged by moderate to high numbers of pests, including aphids (Aphidae), thrips (Tripidae), owlet moth larvae (Noctuidae), white flies (Aleyrodoidae), and mites (Acaridae); later during the cool-dry season, problems started with the fungal disease, anthracnose (Colletotrichum spp.). A Bacillus thuringiensis $(B t)$ product $[B$. thuringiensis ssp. aizawai strain ABTS1857 (XenTari ${ }^{\circledR}$; Valent BioSciences, Libertyville, IL)] and a neem product [Azadirachta indica (BioFree. ${ }^{\circledR}$; Global Ecosys, Taichung City, Taiwan)] were used to manage owlet moth larvae/smallsized insect pests and mites, respectively. During the hot-wet season trial, the $B t$ and neem products were applied weekly as a preventative measure. The biopesticides were applied less frequently during the cool-dry season trial-about every second week, for a total seven times. In addition to the above-mentioned Bt product, a second product that included $B$. thuringiensis ssp. kurstaki (Delfin ${ }^{\circledR}$; Novartis Crop Protection, Greensboro, NC) was used to reduce the risk of resistance build-up in insect pest populations against one of the Bt subspecies. Applications were suspended when it was observed that the neem product was not sufficiently effective, and $B t$ was not needed. Pest management also included physical controls (sticky paper and pheromone traps) and cultural methods (moderate irrigation, field sanitation, cleaning tools, and crop rotation). Plastic film mulch cover on raised beds was used for weed management and improved water use efficiency.

Data COLLECTION AND STATISTICAL ANALYSIS. In both seasons, harvest was performed when the immature fruit reached a shining green color. Sweet pepper harvest during the hot-wet season was from 60 to 142 DAT (nine harvests); during the cool-dry season it was from 92 to 132 DAT (three harvests). Sixteen plants per plot were harvested regularly by hand; plants on the edges of the plots were omitted. Fruit from each plot were graded and weighed immediately after each harvest. The data were statistically evaluated using analysis of variance (procedure GLM of SAS, version 8.2; SAS Institute, Cary, NC). Comparisons of means were carried out using Tukey's test at $P<0.05$.

\section{Results and discussion}

FruIT weIght. In the hot-wet and cool-dry seasons, mean fruit weight of the small-fruited line PP9852-131 was 52 and $63 \mathrm{~g}$, respectively, and was significantly lower compared with the other trial entries in both seasons. The mean fruit weights of the other trial entries ranged from 115 to $183 \mathrm{~g}$ across seasons, and were not significantly different from one another in either season (data not shown). Fruit weight varied with harvest date, but was not necessarily determined by harvest date.

SWEET PEPPER YIELDS DURING THE HOT-wet SEASON. During the hot-wet season 2007, the commercial cultivars and sweet pepper lines both produced relatively high total yields (up to $55.7 \mathrm{t} \cdot \mathrm{ha}^{-1}$ ) and marketable yields (up to $45.6 \mathrm{t} \cdot \mathrm{ha}^{-1}$ ) that were not significantly different from each other (Table 3).

Yields were similar to those in previous field experiments at AVRDC under conventional farming conditions during the hot-wet season. For example, when conventionally managed sweet pepper was transplanted in Mar. 2003, a mean total fruit yield of $36.7 \mathrm{t} \cdot \mathrm{ha}^{-1}$ (range of 20.8-55.0 
Table 3. Mean total and marketable fruit yield during the hot-wet season 2007 and cool-dry season 2007-08 and percent yield reduction in the cool-dry versus hot-wet season of six sweet pepper cultivars and lines, AVRDC-The World Vegetable Center organic fields in Shanhua, Taiwan.

\begin{tabular}{|c|c|c|c|c|c|c|}
\hline \multirow[b]{2}{*}{ Cultivar/line } & \multicolumn{3}{|c|}{ Total yield $^{\mathrm{z}}$} & \multicolumn{3}{|c|}{ Marketable yield } \\
\hline & $\begin{array}{l}\text { Hot-wet } 2007^{y} \\
\left(t \cdot h a^{-1}\right)\end{array}$ & $\begin{array}{c}\text { Cool-dry 2007-08 } \\
\left(\mathrm{t} \cdot \mathrm{ha}^{-1}\right)\end{array}$ & $\begin{array}{c}\text { Reduction }^{\mathrm{w}} \\
(\%)\end{array}$ & $\begin{array}{l}\text { Hot-wet } 2007 \\
\left(\mathrm{t} \cdot \mathrm{ha}^{-1}\right)\end{array}$ & $\begin{array}{c}\text { Cool-dry 2007-08 } \\
\left(\mathrm{t} \cdot \mathrm{ha}^{-1}\right)\end{array}$ & $\begin{array}{l}\text { Reduction } \\
(\%)\end{array}$ \\
\hline $\begin{array}{l}\text { 'Green Bell } \\
\text { Improved' }\end{array}$ & $45.0 \mathrm{a}$ & $40.2 \mathrm{ab}^{\mathrm{v}}$ & -10.7 & $40.3 \mathrm{a}$ & $34.0 \mathrm{a}$ & -15.6 \\
\hline 'Queen Star' & $55.7 \mathrm{a}$ & $37.8 \mathrm{ab}$ & -32.1 & $45.6 \mathrm{a}$ & $31.9 \mathrm{ab}$ & -30.0 \\
\hline 'Hercules' & $53.1 \mathrm{a}$ & $33.3 \mathrm{bc}$ & -37.3 & $41.9 \mathrm{a}$ & $28.8 \mathrm{ab}$ & -31.3 \\
\hline PP9852-131 & $44.6 \mathrm{a}$ & $29.9 \mathrm{bc}$ & -33.0 & $39.9 \mathrm{a}$ & $26.2 \mathrm{ab}$ & -34.3 \\
\hline
\end{tabular}

${ }^{\mathrm{z}}$ Marketable and unmarketable fruit (e.g., adversely affected by blossom end rot, insect pests, mites, and diseases or malformed).

yot-wet season 2007: transplanted on 7 Mar. 2007, harvest duration from 60 to $142 \mathrm{~d}$ after transplanting $(\mathrm{DAT})$, nine harvests; $1 \mathrm{t} \cdot \mathrm{ha} \mathrm{a}^{-1}=0.4461$ ton $/$ acre.

${ }^{x}$ Cool-dry season 2007-08: transplanted on 27 Nov. 2007, harvest duration from 92 to 132 DAT, three harvests.

wercent yield reduction in the cool-dry versus hot-wet season.

"Means within columns followed by different letters are significantly different at $P<0.05$ according to Tukey's test.

"During the cool-dry season COA672 was used instead of COA677; however, both entries are hybrids and their genetic background is very similar including fruit weight (see Table 2).

$\mathrm{t} \cdot \mathrm{ha}^{-1}$ ) and a mean marketable fruit yield of $26.5 \mathrm{t} \cdot \mathrm{ha}^{-1}$ (range of $14.5-$ $\left.41.1 \mathrm{t} \cdot \mathrm{ha}^{-1}\right)$ was achieved across 12 advanced entries; among them was 'Andalus' with a total and marketable yield of $55.0 \mathrm{t} \cdot \mathrm{ha}^{-1}$ and $41.1 \mathrm{t} \cdot \mathrm{ha}^{-1}$, respectively (AVRDC-The World Vegetable Center, 2004). It should be noted that the aim of this study was to collect preliminary data on yields of organically grown sweet pepper cultivars in the tropics rater than to compare different production systems. Therefore, organic sweet pepper yields were not compared side-byside with conventionally grown sweet peppers using the same cultivars, although this method to compare yield data of different production systems is more meaningful than comparisons of yields across years.

SWEET PEPPER YIELDS DURING THE COOL-DRY SEASON. During the cool-dry season 2007-08, the total and marketable yields of all entries were reduced by as much as $46.5 \%$ and $42.3 \%$, respectively, compared with the hot-wet season (Table 3); probably mainly due to unusually low temperatures during the growing season. The commercial hybrid 'Andalus' showed the least decline in total and marketable yields, while the AVRDC test $\mathrm{F}_{1}$ hybrid showed the greatest (see "Discussion"). Particularly in Feb. 2008 during the harvest period, the mean monthly minimum air temperature was relatively low, at $12.9^{\circ} \mathrm{C}$ (see Table 1 ) compared with the long-term monthly mean of $14.5^{\circ} \mathrm{C}$, and may have impacted sweet pepper growth, flowering, fruit set, and fruit development. When air temperatures fall below $18{ }^{\circ} \mathrm{C}$ for extended periods, growth and yield of sweet pepper are usually decreased (Berke et al., 2003). For example, harvest started later during the cooldry (92 DAT) compared with the hotwet $(60$ DAT) season. In addition, fruit were harvested three times during this cool-dry season, while nine harvests were completed during the hot-wet season (see footnote of Table 2). However, we cannot exclude that other factors contributed to the lower yield achieved during the cool-dry season such as the lower number of harvest dates that might have directly reduced yield but also indirectly through reduced fruit set. Large fruit acts as a sink for nutrients, and inhibits the development of additional fruit on the plant (Robinson and Decker-Walters, 1997). Insect pest infestation levels were in general greater during the cool-dry compared with hot-wet season and may have resulted in more plant damage and reduced plant growth and yields. It is unknown why during the hot-wet season the impact of pests (insects and mites) was minor, even though the sweet pepper field trial was a mere $50 \mathrm{~m}$ away from a cucumber (Cucumis sativus) field trial that suffered severe pest infestations. Lower temperatures in the cool-dry season (see Table 1) may have reduced organic nitrogen mineralization processes and resulted in lowered $\mathrm{N}$ availability to the crop. To summarize, earlier crop establishment may have produced higher yields because transplanting in September compared with November is better for attaining extremely high sweet pepper yields in Taiwan (S.C. Shieh, personal communication) as long as temporary flooding and strong winds caused by typhoons do not harm early crop development.

YIELD REDUCTION AMONG TRIAL ENTRIES DURING THE COOL-DRY SEASON. 'Andalus' is tolerant to low temperatures according to the product label. Tolerance to low temperatures is the most plausible explanation for its relative high total and marketable yields during the cooldry season, although its total yield was not significantly different from those of 'Green Bell Improved' and 'Queen Star' (Table 3). However, 'Green Bell Improved', which is noted for heat tolerance, showed like 'Andalus' a relative small reduction of around $10 \%$ in total yield during the cooldry compared with hot-wet season (Table 3). 'Andalus' and 'Green Bell Improved' may be tolerant to high and low temperatures, thus they may produce reliable yields across a relative broad range of locations and seasons.

The influence of temperature on flower development and fruit set of sweet pepper is intensively discussed by Hodges et al. (1995). These authors also found differences in yield among four sweet pepper cultivars that were evaluated for marketable yield across locations, years, and planting dates. Among other factors, these yield differences were related to adaptation to extreme temperatures. For example, in their study, 'Hybelle' appeared to be better adapted to conditions where low temperatures occur during the growing season. 
SWEET PEPPER YIELDS IN ORGANIC AND CONVENTIONAL PRODUCTION SYSTEMS WORLDWIDE. With the longterm field studies of Delate (2002) and Delate et al. $(2003,2008)$, it was also found that sweet pepper yields are similar in organic and conventional production systems. For example, Delate et al. (2008) have recently reported that from 2001 to 2003 , mean marketable yields of sweet pepper were similar in organic $(26.9,15.6$, and $\left.18.8 \mathrm{t} \cdot \mathrm{ha}^{-1}\right)$ and conventional $\left(25.6,15.7\right.$, and $\left.11.0 \mathrm{t} \cdot \mathrm{ha}^{-1}\right)$ production systems that received compost or mineral fertilizer at $112 \mathrm{~kg} \cdot \mathrm{ha}^{-1} \mathrm{~N}$, respectively, in 2 of 3 years. In the third year of their study, the organically managed sweet pepper plants produced a significantly higher fruit yield. These sweet pepper yields were gained under lower input levels compared with the study presented here (300 $\mathrm{kg} \cdot \mathrm{ha}^{-1} \mathrm{~N}$ according to the expected total yield of $50 \mathrm{t} \cdot \mathrm{ha}^{-1}$ applied) and may explain, to a certain extent, the lower yields compared with this study.

Chellemi and Rosskopf (2004) realized up to $30 \mathrm{t} \cdot \mathrm{ha}^{-1}$ of marketable sweet pepper fruit yield in humid subtropical Florida and concluded that organic production systems for fresh market sweet pepper can produce yields similar to those obtained in conventional farming systems. In their study, the maximum marketable yield of conventionally produced sweet pepper was about $37 \mathrm{t} \cdot \mathrm{ha}^{-1}$-similar to the statewide average in Florida of $35.8 \mathrm{t} \cdot \mathrm{ha}^{-1}$ for conventional sweet peppers from 1996 to 2001. The marketable fruit yields reported here are well above $30 \mathrm{t} \cdot \mathrm{ha}^{-1}$ during the hot-wet season and also during the cool-dry season in three commercial cultivars; comparable to those of Cesar et al. (2007) who have realized in a 1 -year study in organically grown sweet pepper an average marketable yield of $37 \mathrm{t} \cdot \mathrm{ha}^{-1}$ across two cultivars and two treatments with a maximum value of $43 \mathrm{t} \cdot \mathrm{ha}^{-1}$.

\section{Conclusions}

The on-station field experiments using organic farming methods reported here found total and marketable fruit yields of sweet pepper similar to those of previous AVRDC cultivar evaluation experiments based on conventional farming techniques. This is in agreement with studies performed in the United States.

Yield data of sweet pepper gained under tropical conditions in Taiwan can assist in evaluating the yield performance of organically produced vegetables under tropical climatic conditions elsewhere. The relatively high yields achieved on-station in tropical Taiwan, which are comparable to those achieved in a 1-year study in Brazil, may encourage farmers and agricultural stakeholders to consider organic farming as a viable alternative to conventional farming systems in tropical and subtropical countries worldwide.

\section{Literature cited}

AVRDC-The World Vegetable Center. 2004. AVRDC report 2003. 23 May 2008. <http://www.avrdc.org/publications/ annual_report/AR_2003.pdf $>$.

AVRDC-The World Vegetable Center. 2008. AVRDC report 2005. 23 May 2008. <http://www.avrdc.org/publications/ a n nual_report/A R_ $2005 /$ AR2005[1]web.pdfs.

Berke, T.G., L.L. Black, R.A. Morris, N.S. Talekar, and J.F. Wang. 2003. AVRDC international cooperators' guide. Suggested cultural practices for sweet pepper. 19 May 2008. <http://www.avrdc.org/ LC/pepper/swtpepper.pdf>.

Bosland, P.W. and E. Votava. 2000. Peppers: Vegetable and spice capsicums. CAB International, Wallingford, UK.

Central Weather Bureau, Taiwan. 2008. Historical data. Weather station records Tainan 1971-2000, 28 May 2008. <http://www.cwb.gov.tw/V5e/index. htm>.

Cesar, M.N.Z., R. de L.D. Ribeiro, P.D. de Paula, J.C. Polidoro, T. da C. Manera, and J.G.M. Guerra. 2007. Performance of sweet pepper under organic cultivation submitted to intercropping with crotalaria and branch pruning. Horticultura Brasileira 25:322-326. (In Portuguese with English abstract).

Chellemi, D.O. and E.N. Rosskopf. 2004. Yield potential and soil quality under alternative crop production practices for fresh market pepper. Renewable Agr. Food Systems 19:168-175.

Council of Agriculture, Taiwan. 2005. Production standards for organic agricultural products-crops. 27 May 2008. <http://organic.niu.edu.tw/oaic-english/ data/Crops.htm>.
Del Amor, F.M. 2007. Yield and fruit quality response of sweet pepper to organic and mineral fertilization. Renewable Agr. Food Systems 22:233-238.

Delate, K. 2002. Using an agroecological approach to farming systems research. HortTechnology 12:345-354.

Delate, K., C. Cambardella, and A. McKern. 2008. Effects of organic fertilization and cover crops on an organic pepper system. HortTechnology 18:215-226.

Delate, K., H. Friedrich, and V. Lawson. 2003. Organic pepper production systems using compost and cover crops. Biol. Agr. Hort. 21:131-150.

De Melo, P.E. 2003. The root systems of onion and Allium fistulosum in the context of organic farming: A breeding approach. Wageningen University, Wageningen, The Netherlands, $\mathrm{PhD}$ thesis.

Hodges, L., D.C. Sanders, K.P. Perry, K.M. Eskridge, K.M. Dean Batal, D.M. Granberry, W.J. McLaurin, D. Decoteau, R.J. Dufault, J.T. Garrett, and R. Nagata. 1995. Adaptability and reliability of yield for four bell pepper cultivars across three southeastern States. HortScience 30:1205-1210.

Juroszek, P., T.A. Lumpkin, W. Easdown, and H.H. Tsai. 2008. Organic vegetable production and research needs in the tropics and subtropics, p. 29-51. In: U. Köpke (ed.). Organic agriculture in the tropics and subtropics, Vol. 1. Intl. Soc. Organic Agr. Res., Bonn, Germany.

Lammerts van Bueren, E.T. 2002. Organic plant breeding and propagation: Concepts and strategies. Wageningen University, Wageningen, The Netherlands, $\mathrm{PhD}$ thesis.

Marin, A., F. Ferreres, F.A. TomasBarberan, and M.I. Gil. 2004. Characterization and quantification of antioxidant constituents of sweet pepper (Capsicum annuum L.). J. Agr. Food Chem. 52:3861-3869.

Robinson, R.W. and D.S. Decker-Walters. 1997. Cucurbits. CAB International, Wallingford, UK.

Scholberg, J., B.L. McNeal, J.W. Jones, K.J. Boote, C.D. Stanley, and T.A. Obreza. 2000. Field-grown tomato: growth and canopy characteristics of fieldgrown tomato. Agron. J. 92:152-159.

United Nations. 2003. Organic fruit and vegetables from the tropics. 25 May 2008. <http://www.unctad.org/en/docs/ ditccom20032_en.pdf>. 